\title{
PERSEPSI WARGA BINAAN PEMASYARAKATAN PEREMPUAN TERHADAP PERAN SEBAGAI IBU: STUDI FENOMENOLOGI
}

\author{
Umi Hani' ${ }^{1}$, Agus Setiawan², Poppy Fitriyani ${ }^{3}$ \\ 1STIKES Karya Husada Semarang, Jl. Kompol R. Soekanto 46 Semarang, 085285797345 \\ 2,3Universitas Indonesia, dengan alamat \\ *umi.hani.ners@gmail.com
}

\begin{abstract}
ABSTRAK
Latar belakang. Jumlah narapidana atau warga binaan pemasyarakatan perempuan terus meningkat sehingga perlu mendapat perhatian. Hal ini berkaitan dengan kebutuhan kesehatannya yang unik serta subyek yang terkena dampak termasuk anak. Pemenjaraan menimbulkan pemikiran, perasaan, sikap, dan gagasan tersendiri bagi warga binaan pemasyarakatan perempuan untuk menjalankan perannya sebagai ibu. Tujuan penelitian. Penelitian ini bertujuan untuk menggali persepsi warga binaan pemasyarakatan perempuan di Rutan Kelas IIA Jakarta Timur dalam menjalankan peran sebagai ibu. Metode. Penelitian menggunakan desain kualitatif dengan pendekatan fenomenologi. Pengumpulan data dilakukan dengan wawancara mendalam terhadap tujuh warga binaan perempuan. Transkrip wawancara dianalisis dengan mengorganisasikan kata kunci yang ditemukan ke dalam kategori, sub tema, dan tema. Hasil. Hasil penelitian menjelaskan bahwa warga binaan pemasyarakatan perempuan memiliki persepsi yang sama tentang peran seorang ibu dalam pengasuhan anak. Peran penting seorang ibu yaitu memperhatikan kesehatan anak, mendidik anak, mendampingi anak, dan mencukupi semua kebutuhan anak. Partisipan tetap dapat menunjukkan perilaku-perilaku positif dan pengasuhan. Partisipan memiliki efikasi diri yang tinggi dalam pengasuhan anak. Kesimpulan. Efikasi diri yang dimiliki ibu berdampak pada persepsi dan kemampuannya untuk menjalankan peran selama dan setelah dipenjarakan. Hasil penelitian ini diharapkan dapat menjadi acuan bagi kolaborasi profesi antara lembaga peradilan, perawat komunitas, akademisi, dan elemen terkait untuk meningkatkan perhatian terhadap pelaksanaan peran ibu di lembaga pemasyarakatan
\end{abstract}

Kata kunci: pemenjaraan; pengasuhan; peran sebagai ibu; warga binaan pemasyarakatan

\section{PERCEPTION OF FEMALE INMATE ON ROLE AS MOTHER: PHENOMENOLOGY STUDY}

\begin{abstract}
The number of female inmate continues to increase and needs attention. It is related to their unique health needs as well as affected subjects including children. Imprisonment creates their own thoughts, feelings, attitudes, and ideas for women in prison to carry out their role as mothers. This study was aimed to explore the perceptions of female inmate in Class IIA detention centers in East Jakarta in carrying out their role as mothers. The study used a qualitative design with a phenomenological approach. Data was collected by in-depth interviews of seven female inmates. Interview transcripts were analyzed by organizing the keywords found into categories, sub themes, and themes. The results of the study explained that female inmates have the same perception about the role of a mother in childcare. An important role of a mother is to pay attention to children's health and education, accompany their children, and meet all the needs of children. Participants can still show some positive parenting behaviors. The self-efficacy of the mother has an impact on her ability to perform roles during and after imprisonment. The results of this study are expected to be a reference for professional collaboration between the judiciary, community nurses, academics, and related elements to raise awareness of imprisoned mothers and children affected by female inmate.
\end{abstract}

Keywords: imprisonmen; parenting; mother's role; female inmate 


\section{LATAR BELAKANG}

Lembaga Pemasyarakatan (Lapas) merupakan tempat untuk melaksanakan pembinaan bagi narapidana dan anak didik pemasyarakatan (Kementerian Hukum dan Hak Asasi Manusia, 1995). Sejumlah orang yang dijatuhi hukuman penjara atau kurungan berdasarkan keputusan pengadilan dibina di Lapas dalam jangka waktu yang telah diputuskan dan disebut warga binaan pemasyarakatan (WBP). Sedangkan seseorang yang ditahan karena menunggu proses peradilan disebut tahanan. $\mathrm{Di}$ Indonesia, pelaksanaan penghukuman dan pembinaan pelanggar hukum dilakukan dengan mempergunakan filosofi pemasyarakatan, yaitu suatu konsep yang bertujuan agar pembinaan di dalam penjara mampu mengembalikan narapidana ke masyarakat dengan berhasil (Yunardhani, 2013).

Jumlah perempuan yang dipenjara terus mengalami peningkatan hampir delapan kali sejak tahun 1980. Jumlah wanita yang dipenjara meningkat lebih dari $750 \%$ antara Tahun 1980 dan 2017, yaitu meningkat dari total 26.378 pada tahun 1980 menjadi 225.060 pada Tahun 2017 (The Sentencing Project, 2018; Walmsley, 2017). Di Indonesia, persentase jumlah Warga Binaan Pemasyarakatan (WBP) perempuan dibandingkan dengan total keseluruhan narapidana cenderung mengalami peningkatan sejak tahun 2000-2015 berturutturut 3.4\%, 4.7\%, 5.8\%, dan 5.4\%. Tahun 2016 terdapat 9.844 WBP perempuan atau $5,5 \%$ dari jumlah total WBP di Indonesia (World Prison Brief, 2016). Berdasarkan jumlah warga binaan perempuan tersebut, DKI Jakarta (1107) menjadi kota terbesar ketiga setelah Sumatra Utara (1352) dan Jawa Timur (1211) (Sistem Data Base Pemasyarakatan, 2017).

Data jumlah penghuni per Juni 2017 Sistem Database Pemasyarakatan menunjukkan kapasitas berlebih di Jakarta yaitu 564 tahanan perempuan yang ditempatkan di Rutan Kelas IIA Jakarta Timur dan 543 WBP perempuan yang ditempatkan di Lapas Perempuan Kelas IIA Jakarta. Jumlah total tahanan dan narapidana tersebut melebihi kapasitas Rutan dan Lapas yaitu 827 (Sistem Data Base Pemasyarakatan, 2017). Jumlah ini menunjukkan perlunya kajian dalam sistem pemasyarakatan bagi WBP perempuan.

Glaze dan Maruschak (2008) menyebutkan $62 \%$ narapidana perempuan di Amerika Serikat memiliki anak di bawah 18 tahun. Sejak Tahun 1991, jumlah anak dengan ibu di penjara meningkat lebih dari dua kali lipat, naik 131\%, sedangkan jumlah anak dengan ayah di penjara telah tumbuh sebesar $77 \%$. Temuan ini mencerminkan tingkat pertumbuhan yang lebih cepat dalam jumlah ibu yang ditahan di penjara (naik 122\%), dibandingkan dengan jumlah ayah (naik 76\%) antara 1991 dan pertengahan tahun 2007 (Glaze \& Maruschak, 2010; The Sentencing Project, 2018). Di Indonesia sendiri, belum ada data nasional yang menyebutkan jumlah WBP perempuan yang memiliki anak. Namun, sebuah studi di dua rumah tahanan peremuan di Indonesia menyebutkan $69 \%$ perempuan yang ditahan memiliki anak dan mereka menghadapi berbagai kendala dalam perannya sebagai ibu (Mustofa et al., 2019; Wildeman \& Turney, 2014).

Selama ibu ditahan di penjara, 37\% anak yang diasuh oleh ayahnya selama ibu di penjara, 45\% anak-anak diasuh oleh kakek atau nenek, 23\% oleh kerabat lain dan 19\% oleh lembaga sosial (Glaze \& Maruschak, 2010; Wildeman \& Turney, 2014). Pemenjaraan mengakibatkan putus kontak dan kehilangan komunikasi dengan kerabat termasuk suami, dan kecemasan terhadap kondisi anak-anak yang ditinggalkan serta pemenuhan kebutuhan anak-anak setelah keluar dari penjara (Easterling \& Johnson, 2015; Mustofa et al., 2019). Keterbatasan kontak antara ibu yang dipenjarakan dengan keluarga terutama anaknya, membuat mereka harus mempertaruhkan perannya sebagai ibu.

Peraturan Pemerintah Nomor 32 Tahun 1999 Pasal 20 tentang Syarat dan Tata Cara Pelaksanaan Warga Binaan Pemasyarakatan menyebutkan bahwa WBP perempuan boleh membesarkan anaknya dalam lapas sampai anak berusia dua tahun, sesuai masa ASI yang diperlukan seorang anak untuk pertumbuhannya. Hal ini mendukung kelekatan antara ibu dan anak di tahun-tahun awal kehidupan anak. Namun demikian, jaminan hak 
untuk merawat dan mengasuh anak ini belum didukung dengan fasilitas untuk anak, kamar dan juga kelayakan tempat tinggal untuk anak baik dari lingkungan sosial maupun kebersihan. Selain itu, kebijakan menutup pintu kamar membuat anak-anak turut "terpenjara" bersama (Departemen Hukum dan HAM Republik Indonesia., 2009; Mustofa et al., 2019).

Kjellstrand dan Eddy (2011) menjelaskan teori pembelajaran interaksi dari Patterson, DeBaryshe, dan Ramsey (1989) menjadi landasan konsep keterkaitan antara pemenjaraan orang tua, fungsi keluarga, strategi pengasuhan (parenting), dan perilaku sosial anak (Kjellstrand \& Eddy, 2011). Parenting merupakan cara orang tua mendidik anak yang mana melibatkan emosional dalam interaksi yang dibangun. Kurangnya kesiapan orang tua dalam upaya parenting merupakan faktor risiko meningkatnya masalah kesehatan baik pada usia anak maupun dewasa (StewartBrown, 2008). Hal ini menggeser paradigma masyarakat bahwa dukungan terhadap orang tua merupakan cara paling efektif untuk meningkatkan kesehatan, kesejahteraan, dan tumbuh kembang anak. Oleh karena itu, munculnya dampak negatif pada anak karena pemenjaraan ibu perlu dikaitkan dengan kesiapan ibu dalam melanjutkan perannya sebagai orang tua setelah keluar dari penjara. Penelitian ini bertujuan untuk melihat persepsi ibu dalam menjalankan perannya selama pemenjaraan.

\section{METODE}

Penelitian ini menggunakan desain kualitatif dengan pendekatan fenomenologi deksriptif. Pengumpulan data dilakukan melalui wawancara mendalam dengan alat bantu perekam suara dan catatan lapangan. Alat perekam dipilih karena pengalaman yang diungkapkan oleh partisipan tidak memungkinkan untuk dicatat langsung oleh peneliti. Penggunaan alat perekam tersebut atas persetujuan partisipan serta lembaga pemasyarakatan sebagai aspek etik dan legal dalam penelitian kualitatif (Denise \& Beck, 2013; Valdez et al., 2017). Dalam proses pengumpulan data yang telah dilakukan, peneliti hanya dapat mengandalkan satu alat perekam suara karena adanya larangan membawa alat elektronik ke dalam lembaga pemasyarakatan.

Catatan lapangan berisi respon nonverbal yang diekspresikan partisipan ketika menyampaikan pengalamannya tentang fenomena yang diteliti, serta untuk mencatat kondisi lingkungan selama proses wawancara.

Partisipan dipilih sesuai tujuan penelitian terhadap 7 WBP perempuan di Rutan Kelas IIA Jakarta Timur dan Lembaga Pemasyarakatan Kelas IIA Jakarta. Wawancara dilakukan April sampai JUni 2017. Transkrip hasil wawancara kemudian dianalisis dengan metode analisis konten tematik dengan pendekatan Colaizzi. Analisis dilakukan dengan mengorganisasikan kata kunci yang ditemukan ke dalam kategori, sub tema, dan tema (Denise \& Beck, 2013; Valdez et al., 2017).

Penelitian telah dinyatakan lolos kaji etik oleh Komite Etik Penelitian Fakultas IImu Keperawatan Universitas Indonesia No.138/UN2.F12.D/HKP.02.04/2017 tanggal 27 April 2017.

\section{HASIL}

\section{Karakteristik partisipan}

Partisipan merupakan tahanan di Rutan Kelas IIA Jakarta Timur dan Lapas Perempuan Kelas IIA Jakarta dengan masa hukuman 2 tahun sampai 7 tahun. Mayoritas partisipan terlibat dalam penyalahgunaan narkoba (5 dari 7 partisipan).

Usia partisipan berkisar 29-35 tahun dengan status menikah. Namun, dua partisipan pernah bercerai dan kembali menikah. Semua partisipan memiliki anak paling sedikit satu dan paling banyak 6 anak. Empat dari tujuh partisipan tinggal bersama seorang anaknya di Rutan yang berusia kurang dari 2 tahun. Seorang partisipan juga sedang hamil anak ke4.

Semua partisipan berdomisili di daerah Jakarta sebelum mengalami pemenjaraan. Pendidikan partisipan rata-rata SD sampai SMA, tetapi terdapat seorang partisipan yang 
berpendidikan S1. Sebelum pemenjaraan, partisipan rata-rata bekerja sebagai buruh, karyawan swasta, dan ibu rumah tangga.

\section{Karakteristik anak di rutan}

Empat dari tujuh partisipan merawat anaknya di rutan. Anak tinggal bersama ibu di dalam sel penjara dengan aktivitas pengasuhan yang terbatas. Anak berusia antara 2 minggu sampai 1,5 tahun. Beberapa anak dalam usia 0-6 bulan sudah tidak mendapat ASI eksklusif melainkan susu tambahan yang diberikan secara gratis oleh klinik rutan dalam jumlah yang terbatas. Sebagian besar anak juga sudah diberikan bubur susu instan sebelum berusia 6 bulan.

\section{Interpretasi Analisis Tema}

Tema 1: perilaku positif ibu dalam pengasuhan anak selama pemenjaraan

Perilaku positif ibu dalam pengasuhan mencakup interaksi yang terjaga dengan anak dan perhatian untuk anak.

Sub tema 1: interaksi yang terjaga dengan anak Meskipun dalam situasi pemenjaraan, partisipan berusaha menjaga hubungan dengan anak baik melalui surat, telepon, maupun jadwal kunjungan anak.

"yang pasti untuk anak sampai hari ini tetep konsen ke anak, cuman by phone" (P3)

"walaupun dia ga tinggal sama saya ya. Tapi minimal komunikasi dengan anak saya, saya telepon anak saya" (P2)

\section{Sub tema 2: perhatian untuk anak}

Partisipan memperhatikan kondisi anak, mendoakan anak dan bekerja selama di rutan/Lapas untuk memenuhi kebutuhan anak. Partisipan menilai dirinya masih mampu memberi perhatian kepada anak serta menjaga interaksi dengan anak meskipun dalam kondisi pemenjaraan.

\footnotetext{
"makanya di sini, biarpun kayak gimanapun, suka miketin orang ngelimpahin ke saya, biarpun tiga puluh ribu, saya lakukan demi apa? Demi anak kan" (P6)
}

\begin{abstract}
"Trus aku selalu wanti-wanti em belajarnya dia gimana, jadi mamaku mengerti ya karena kan memang basicly mamaku dulunya bekerja jadi dia tau gitu, trus yang kecil gimana? Susunya gimana Ma? Makannya gimana? Trus sakit atau enggak? Trus kalau seandainya dia sakit karena saya ada pengalaman, o jangan dikasih ini mah, jangan begini mah, atau mama ke dokter lebih baik tanya, mendingan cerewet gitu itu jadi tetep sharing sama mamaku." (P3)
\end{abstract}

Partisipan yang terpisah dari anaknya menjadikan doa sebagai upaya yang dapat dilakukan sebagai ibu.

"saya selalu berdoa sama Tuhan, Tuhan
selama saya ga ada, selama saya ga
bisa komunikasi, kasihlah anak saya ini
pergaulan yang bener-bener, takut akan
Engkau lah." (P2)

Skema tematik tema ini dapat dilihat pada bagan 1 sebagai berikut.

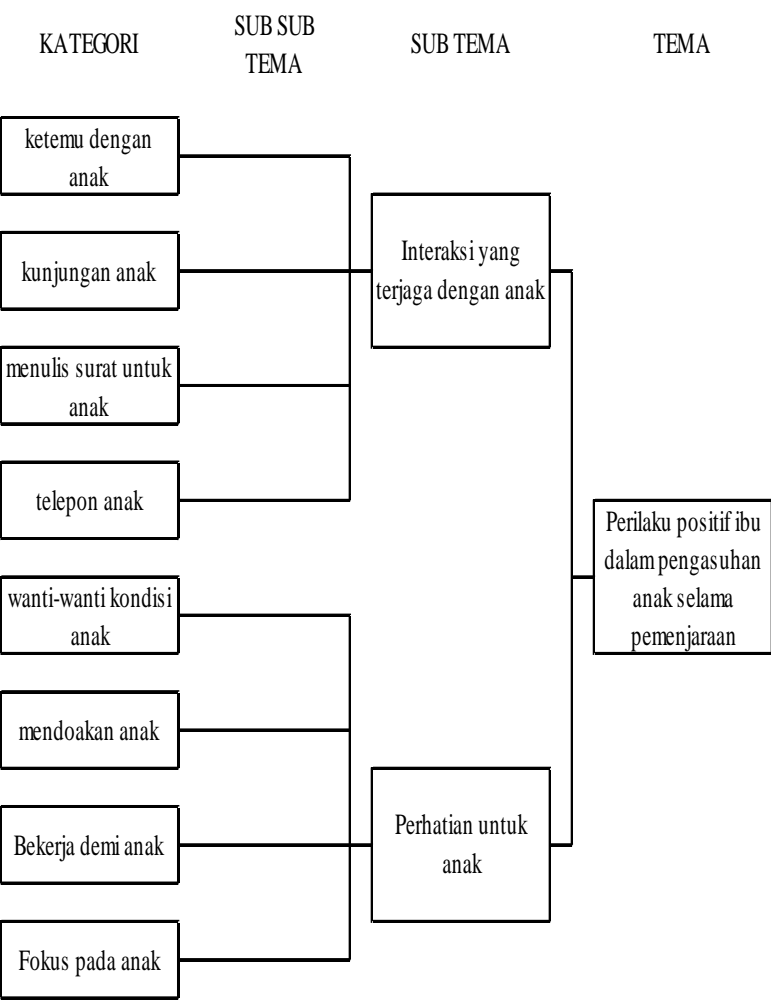

Bagan 1 Skema Tematik Perilaku Positif Ibu dalam Pengasuhan Anak selama Pemenjaraan 
Tema 2: Efikasi diri ibu yang tinggi dalam pengasuhan anak

Tema ini diangkat dari tiga sub tema yaitu keyakinan terhadap kemampuan diri dalam pengasuhan, harapan ibu dalam pengasuhan anak, dan pandangan ibu mengenai perilaku mengasuh yang benar.

Sub tema 1: keyakinan terhadap kemampuan diri dalam pengasuhan

Partisipan mengekspresikan keyakinannya dalam merawat anak dengan baik dan dapat memenuhi perannya sebagai ibu meskipun dalam situasi pemenjaraan. Kategori dari kata kunci yang ditemukan antara lain pernyataan ibu dapat mengasuh anak selama di rutan, belajar dari pengalaman pengasuhan yang diterima, serta pengalaman sebagai ibu dari beberapa anak. Partisipan juga mengungkapkan harapannya untuk menjalankan perannya dalam pengasuhan dengan lebih baik setelah bebas.

Keyakinan yang dimiliki ibu dalam kemampuan yang dimiliki untuk merawat anak diungkapkan partisipan sebagai berikut.

"ya..namanya udah jadi ibu dari dulu, udah tau musti gimana ngurus anak" (P6)

"saya ngasuh anak yang bener, saya juga ngasih nafkah rutin," (P5)

Partisipan juga mengekspresikan keyakinannya untuk merawat anak di penjara.

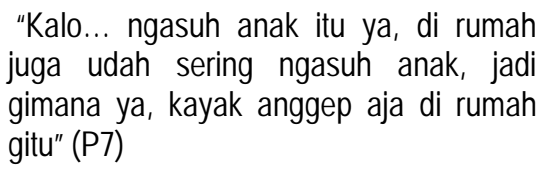

Partisipan memiliki pengalaman yang baik dalam pengasuhan anak sehingga menilai dirinya akan mampu menerapkan gaya pengasuhan yang baik pula.

"Saya punya latar belakang orang tua yang selalu ngajarin anaknya tuh untuk open" (P3)
Selain itu, pemenjaraan dirasakan ibu untuk dapat menjadi ibu yang lebih baik saat bebas nanti.

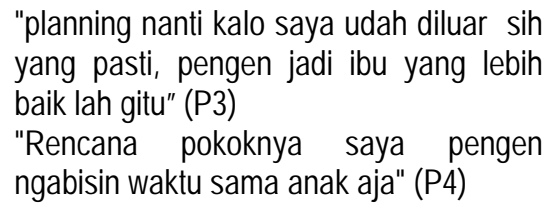

Sebagian partisipan baru merasakan mengasuh anak secara langsung, tetapi partisipan juga memiliki keyakinan untuk menjadi ibu yang baik.

"...kalo ngasuh, saya baru ini... Jadi ya

kayak masih belajar-belajar juga si" (P1)

Sub tema 2: harapan ibu dalam pengasuhan anak

Sub tema ini dibangun dari beberapa kategori yang menunjukkan keinginan ibu terhadap kemampuannya untuk memberikan perhatian kepada anak. Kategori yang membangun yaitu keinginan untuk memberi anak uang jika ada. Partisipan juga mengungkapkan harapannya agar anak menjadi lebih baik dan tidak dipenjara.

\footnotetext{
"Ya kalo saya ada duit, saya kasih buat jajan dia" (P2)

"biarpun saya kerja asal nyuci bisa ngasih kan seneng hati, meskipun 50ribu juga, daripada kita gak ngasih anak sama sekali kan?" (P6)
}

Partisipan melihat dirinya dalam situasi pemenjaraan, menginginkan anak bisa lebih baik dan sebagian partisipan menginginkan anaknya tidak tinggal di lingkungan pemenjaraan.

\footnotetext{
"Harapan saya ke depannya, saya mau ngliat anak saya lebih baik" (P2)

"Kalo misalnya itu... saya pengennya dia di luar juga," (P6)
}

Partisipan merencanakan untuk memperbaiki peran sebagai ibu setelah bebas. 
"pokoknya keluar dari sini apapun itu saya harus tebus kesalahan saya sama anak-anak" (P3)

Sub tema 3: pandangan ibu mengenai perilaku mengasuh yang benar

Efikasi diri dalam menjalankan peran juga mencakup bagaimana seseorang memandang perannya. Terdapat empat kategori yang membangun sub tema ini yang meliputi mendidik anak, memenuhi kebutuhan anak, membersamai anak, dan menjaga kesehatan anak.

Partisipan sebagai ibu, menjalankan perannya dengan berusaha memberi perhatian penuh terhadap anak, baik dari segi materi maupun kasih sayang. Semua partisipan memiliki pandangan yang sama tentang tanggung jawab seorang ibu terhadap anak. Semua partisipan berpandangan bahwa hal paling penting sebagai seorang ibu yaitu memperhatikan kesehatan anak, mendidik anak, membersamai anak, dan mencukupi semua kebutuhan anak.

"menjaganya, mendidiknya, memperhatikannya, dan memberi kasih sayang untuk dia.." (P5)

"dididiknya yang bener." "misalnya ya. bicaranya, gitu. Kita musti ngomong sama anak yang sopan, atau gimana kalo (anak saya) ini kan setaun, ini, udah masuk ke otak." (P7)

Peran ibu dalam mencukupi semua kebutuhan anak juga dinyatakan oleh P4 dan P7 sebagai berikut.

\footnotetext{
"Yah.. semuanya yah dari, eeh makannya...terus eeh segala kebutuhannya lah pokoknya." (P4)

"Ya makannya, gitu, susunya, ya...inian dia aja, ya inian dia aja, mandi apa, gitu..." (P7)
}

Partisipan di samping berperan utama dalam pengasuhan anak, beberapa sebagai orang tua tunggal yang harus bekerja untuk memenuhi kebutuhan anak. Namun demikian, anak masih menjadi perhatian utama bagi ibu. "biarpun ketika bekerja, komunikasi saya dengan anak-anak baik, saya di rumah pun komunikasi saya dengan anak-anak baik" (P3)

Kebersamaan dengan anak, bagi partisipan adalah hal penting dalam pengasuhan. Dalam situasi pemenjaraan pun partisipan mengatur waktu antara membersamai anak dan menyelesaikan pekerjaannya."
"Jadi pas dia bangun, aku main ama dia gitu" (P1)
"waktu-waktu yang kayak gitu yang menurut orang biasa aja, sangat berarti bagi saya" (P3)

Skema tematik tema ini dapat dilihat pada bagan 2 sebagai berikut.

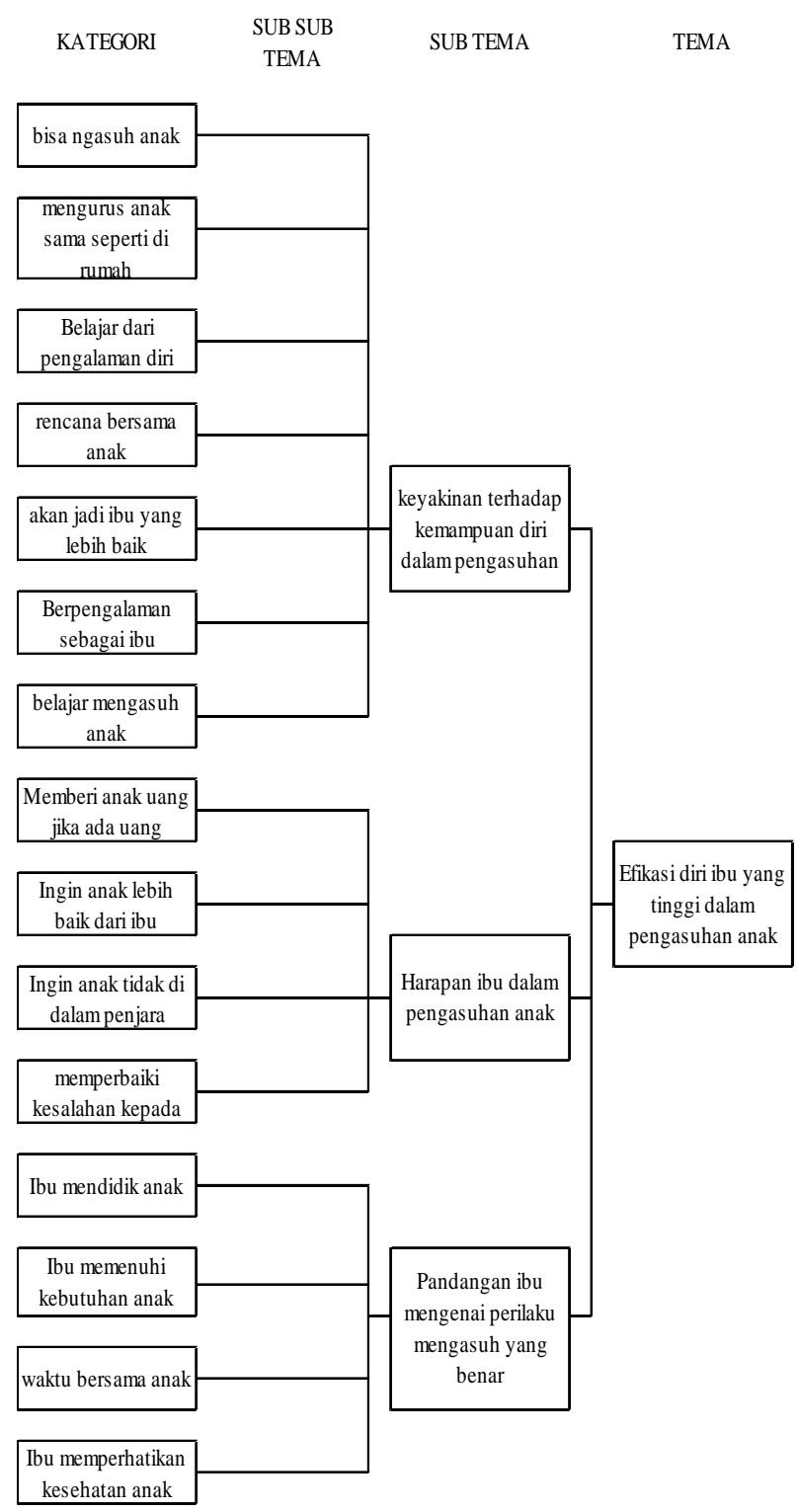

Bagan 2 Skema Tematik Efikasi Diri lbu yang Tinggi dalam Pengasuhan Anak 


\section{PEMBAHASAN}

Karakteristik ibu yang dipenjarakan

WBP perempuan menghadapi situasi khusus berkaitan dengan perannya sebagai ibu. Sebagian besar tahanan dan narapidana perempuan memiliki anak baik yang tinggal bersama di Rutan atau Lapas (anak berusia kurang dari 2 tahun) maupun terpisah (Constantino et al., 2013; Mustofa et al., 2019).

Pada umumnya, WBP perempuan merupakan pengasuh utama bagi anak sebelum pemenjaraan. Sebagian mereka juga menjadi penopang keuangan keluarga untuk memenuhi kebutuhan. Seorang partisipan dalam penelitian ini bahkan menjadi orang tua tunggal karena pemenjaraan yang dialami pasangannya. Namun demikian, bagi sebagian WBP perempuan, pemenjaraan juga menjadikan kesempatan untuk mengasuh anak di Rutan. $\mathrm{Hal}$ ini sebagaimana penelitian yang sebelumnya bahwa pemenjaraan menjadi pengalaman bagi ibu untuk mengasuh anaknya, dan juga menjadi pengalaman bagi ibu terpisah dengan anak yang sedang dirawatnya (Cardaci, 2014; Glaze \& Maruschak, 2010; Kjellstrand \& Eddy, 2011; Mustofa et al., 2019).

Pemenjaraan mengakibatkan beberapa ibu yang terlibat dalam penelitian ini harus kehilangan hak asuh anaknya sebagai konsekuensi menitipkan anak selama pemenjaraan. Pengasuh anak saat ibu mengalami pemenjaraan memenuhi semua kebutuhan anak sehingga menginginkan anak menjadi milik pengasuh sepenuhnya.

\section{Persepsi Positif Ibu di Penjara}

Orang tua berperan penting dalam kehidupan anak khususnya dalam awal-awal tahun perkembangan anak yang mencakup perkembangan fisik, sosial, dan emosional. Pengasuhan mencakup situasi emosional dalam hubungan antara anak dengan orang tua serta upaya orang tua dalam menerapkan pengasuhan kepada anak (Rana et al., 2013). Gaya pengasuhan yang dilakukan orang tua akan berdampak terhadap perkembangan anak. Pengasuhan positif akan berdampak pada lingkungan yang sehat dan mendukung bagi anak, sedangkan pengasuhan yang negatif menimbulkan kecemasan pada anak yang mengakibatkan berbagai masalah psikologis anak.

Ibu yang dipenjarakan menghadapi situasi sulit untuk melakukan pengasuhan. Stressor terbesar bagi mereka adalah kekhawatiran terhadap kondisi anak serta kesedihan karena terpisah dengan anak (Loper \& Tuerk, 2011; Wildeman \& Turney, 2014). Loper dan Tuerk lebih lanjut menjelaskan bahwa ibu di penjara kesulitan untuk berkomunikasi dengan anak, memiliki masalah dengan pengasuh anak, dan kesulitan untuk mengkomunikasikan kepada anak situasi pemenjaraan yang dialami ibu. WBP yang tinggal bersama anak selama pemenjaraan kurang memiliki kebebasan dalam pemenuhan kebutuhan anak di lingkungan Rutan atau Lapas. Selain itu, narapidana yang terpisah dengan anaknya juga kesulitan untuk menjaga interaksi dengan anak yang terpisah karena pemenjaraan. Namun, narapidana perempuan sebagai ibu tetap memperlihatkan perilaku positif dalam pengasuhan yang disesuaikan dengan situasi pemenjaraan yang mereka hadapi.

Ibu yang tinggal bersama anaknya di lingkungan Rutan atau Lapas tetap berupaya untuk memenuhi kebutuhan anak. WBP perempuan berupaya keras untuk dapat memenuhi kebutuhan anaknya dan memandang dirinya memegang tanggung jawab penuh untuk memberikan pengasuhan terbaik. Selain itu, ibu yang terpisah dengan anaknya karena pemenjaraan juga memperhatikan kondisi anak dengan bertanya secara intensif tentang keadaan anak kepada pengasuh. Beberapa narapidana tetap menjaga komunikasi dengan anak melalui telepon, beberapa melalui surat, dan juga kunjungan anak.

\section{Efikasi diri ibu yang tinggi dalam pengasuhan anak}

Efikasi diri dalam pengasuhan didefinisikan sebagai keyakinan atau penilaian orang tua terhadap kompetensi dirinya dalam melaksanakan tugas-tugas pengasuhan anak. Efikasi diri dalam pengasuhan juga akan mempengaruhi kesiapan ibu dalam 
menjalankan kembali peran dalam keluarga ketika bebas (Coleman \& Karraker, 2000; Glatz \& Buchanan, 2015)

Dalam konteks pemenjaraan, efikasi diri dalam pengasuhan menggambarkan keyakinan, penilaian, atau harapan yang dipegang oleh narapidana perempuan tentang kemampuan mereka dalam memberikan pengasuhan meskipun dalam situasi pemenjaraan.

Efikasi diri merupakan kepercayaan pada kemampuan diri dalam mengatur dan melaksanakan suatu tindakan yang diperlukan dalam rangka pencapaian hasil usaha (Glatz \& Buchanan, 2015; Magee, 2016). Efikasi diri mempengaruhi perilaku seseorang serta ketahanan seseorang dalam menghadapi masalah dan tekanan dari lingkungan sosialnya.

Efikasi diri pengasuhan yang dimiliki ibu yang dipenjarakan ditunjukkan dengan keyakinan yang diungkapkan oleh partisipan. Ibu merasa yakin dengan kemampuannya untuk mengasuh anak meski di penjara karena mereka menganggap pengasuhan anak sebagaimana dilakukan di luar penjara. Selain itu, WBP perempuan juga memiliki panutan gaya pengasuhan dari orang tuanya yang menjadi acuan bagi partisipan untuk melakukan pengasuhan yang baik bagi anaknya. Hal ini sejalan dengan studi sebelumnya bahwa efikasi diri sebagai pernyataan subyektif berupa keyakinan individu akan kemampuan dirinya dalam mengontrol perilaku dan tuntutan sosial lingkungan, sehingga memperoleh hasil yang maksimal bagi dirinya (Magee, 2016). Aspek keyakinan terdapat dalam mengontrol lingkungan dan perilakunya bagi individu yang bersangkutan. Keyakinan ini menjadi kekuatan bagi ibu di penjara untuk mampu melewati kesulitan pengasuhan dalam situasi pemenjaraan.

Efikasi diri juga mencakup aspek motivasional yaitu keinginan untuk melakukan suatu tugas, kendala, mapun tuntutan sosial dalam rangka pencapaian hasil yang maksimal. WBP perempuan sebagai ibu memiliki keinginan untuk memperbaiki fungsi perannya sebagai ibu. Pemenjaraan menjadikan WBP perempuan berkeinginan menjadi ibu yang lebih baik saat bebas nanti. Selain itu, ibu yang dipenjarakan menjalani pemenjaraan dengan tetap mengupayakan pemenuhan kebutuhan anak. Hal ini ditunjukkan dengan beberapa partisipan yang bekerja selama di rutan untuk memenuhi kebutuhan anak. Partisipan yang terpisah dari anak juga bekerja untuk dapat memberi nafkah untuk anaknya, serta mengupayakan untuk menjaga interaksi dengan anak.

Hasil penelitian menunjukkan WBP perempuan memiliki efikasi diri ibu yang tinggi dalam pengasuhan meskipun dalam situasi pemenjaraan. Hal ini sejalan dengan studi sebelumnya yang menunjukkan bahwa lingkungan tempat tinggal tidak berpengaruh terhadap efikasi diri orang tua. Lingkungan di penjara menimbulkan dampak psikologis bagi ibu, tetapi tidak mempengaruhi keyakinan diri ibu terhadap kemampuannya untuk melakukan pengasuhan (Magee, 2016). Akan tetapi, sikap ibu dalam menghadapi stressor yang ada akan mempengaruhi efikasi diri.

Studi tersebut juga menunjukkan bahwa jumlah anak memiliki korelasi negatif yang kecil dengan efikasi diri dalam pengasuhan. Namun, hal ini terjadi sebaliknya dalam situasi pemenjaraan. Ibu yang telah memiliki sedikitnya dua anak justru memiliki efikasi diri dalam pengasuhan yang tinggi. Hal ini berkaitan dengan semakin banyaknya pengalaman pengasuhan yang telah dimiliki, sehingga ibu menilai dirinya juga mampu mengasuh anak meski dalam situasi pemenjaraan. Lebih lanjut, Magee menemukan bahwa tingkat pendidikan tidak memiliki hubungan yang signifikan dengan efikasi diri ibu dalam pengasuhan. Hal ini sebagaimana dalam penelitian ini yang melihat bahwa efikasi diri yang tinggi diungkapkan oleh WBP perempuan baik dengan tingkat pendidikan dasar, menengah, maupun perguruan tinggi.

Pemenjaraan menimbulkan pemikiran, perasaan, sikap, dan gagasan tersendiri bagi WBP untuk menjalankan perannya sebagai ibu. Hasil penelitian menunjukkan bahwa WBP perempuan memiliki persepsi yang sama tentang peran seorang ibu dalam pengasuhan anak. Peran penting seorang ibu yaitu memperhatikan kesehatan anak, mendidik anak, mendampingi anak, dan mencukupi semua kebutuhan anak. Meskipun ibu harus menghadapi tuntutan ekonomi dalam hidup, 
narapidana perempuan menyadari bahwa tugas utama mereka adalah mengasuh anak.

Pandangan yang dimiliki mengenai peran ibu serta situasi pemenjaraan yang dialami berkaitan dengan efikasi diri ibu dalam pengasuhan. Peningkatan efikasi diri dalam pengasuhan penting untuk diupayakan karena tidak hanya membantu orang tua menikmati dan merasa puas dalam menjalankan perannya sebagai orang tua, tetapi juga penting dalam menghentikan perilaku pengasuhan tidak efektif yang sering terjadi turun temurun. Oleh karena itu, penting diketahui faktor-faktor yang diperkirakan dapat mengubah efikasi diri dalam pengasuhan. Sebagaimana dalam studi sebelumnya bahwa faktor-faktor yang mempengaruhi perubahan efikasi diri dalam pengasuhan yaitu perubahan fisik pada anak, harapan ibu terhadap anak, kualitas komunikasi ibu dan anak, dan budaya (Glatz \& Buchanan, 2015).

\section{KESIMPULAN DAN SARAN}

Warga Binaan Pemasyarakatan perempuan sebagai ibu memperlihatkan perilaku positif dalam pengasuhan dengan menyesuaikan pengasuhan terhadap situasi pemenjaraan. Ibu yang tinggal bersama anaknya di lingkungan Rutan atau Lapas tetap berupaya untuk memenuhi kebutuhan anak. Sedangkan ibu yang terpisah dari anaknya tetap berusaha menjaga komunikasi dengan anak.

WBP perempuan memiliki efikasi diri yang tinggi dalam pengasuhan. Ibu merasa yakin dengan kemampuannya untuk mengasuh anak meski di penjara karena mereka menganggap pengasuhan anak sebagaimana dilakukan di luar penjara. Lingkungan di penjara menimbulkan dampak psikologis bagi ibu, tetapi tidak mempengaruhi keyakinan diri ibu terhadap kemampuannya untuk melakukan pengasuhan. Akan tetapi, sikap ibu dalam menghadapi stressor yang ada akan mempengaruhi efikasi diri. Efikasi diri tersebut tidak dipengaruhi oleh tingkat pendidikan dan lingkungan pemenjaraan.

Lembaga pemasyarakatan atau rumah tahanan semestinya mengupayakan untuk meningkatkan kesiapan ibu dalam menjalankan kembali peran dalam keluarga khususnya peran sebagai ibu. Konsep pemasyarakatan pada lembaga peradilan di Indonesia menjadi dukungan eksternal bagi WBP perempuan yang memandang pemenjaraan sebagai waktu bagi ibu untuk memperbaiki diri dan berubah menjadi pribadi yang lebih baik dalam menjalankan perannya untuk anak.

Peran pengasuhan yang dilakukan ibu dalam situasi pemenjaraan menunjukkan perlunya pendekatan berbagai profesi dalam sistem pembinaan pemasyarakatan. Kolaborasi lintas profesi antara perawat dan tenaga kesehatan lainnya seperti psikolog, dokter, dan ahli gizi diharapkan dapat mengupayakan situasi pemenjaraan yang memiliki pengaruh besar terhadap pelaksanaan peran ibu.

\section{REFFERENSI}

Cardaci, R. (2014). "If she can do it, so can I" An ethnograpy of a supportive living environment for women in the criminal justice system and their children. ProQuest Dissertations and Theses, 234. http://search.proquest.com.ezpprod1.hul.harvard.edu/docview/1548716555?a ccountid $=11311 \% 5 \mathrm{Cnhttp}: / /$ sfx.hul.harvard.ed u/hvd?url_ver=Z39.88-

2004\&rft_val_fmt=info:ofi/fmt:kev:mtx:dissertati on\&genre=dissertations $+\% 26+$ theses\&sid=Pro Q:ProQuest+Dissertations+\%26+

Coleman, P. K., \& Karraker, H. K. (2000). Parenting self-efficacy among mothers of school-age children: Conceptualization, measurement, and correlates. Family Relations: An Interdisciplinary Journal of Applied Family Studies, 49(1), 13-24. https://doi.org/10.1111/j.17413729.2000.00013.x

Constantino, R., Crane, P., \& Young, S. (2013). Forensic nursing: evidence-based principles and practice. FA Davis Company. https://books.google.co.id/books?id=ccTZAAA $A Q B A J \&$ printsec=frontcover\&source=gbs_ge summary_r\&cad $=0 \# v=0$ nepage $\& q \& f=$ false

Denise, F. P., \& Beck, C. T. (2013). Essentials of Nursing Research Seventh Edition Appraising Evidence for Nursing Practice. In Journal of Chemical Information and Modeling (Vol. 53). https://doi.org/10.1017/CB09781107415324.0 04

Departemen Hukum dan HAM Republik Indonesia. (2009). Peraturan Menteri Hukum dan Hak 
Asasi Manusia Republik Indonesia NOMOR: M.HH-OT.02.02 Tahun 2009 tentang Cetak Biru Pembaharuan Pelaksanaan Sistem Pemasyarakatan. Berita Negara No.5 Tahun 2009. 5.

Easterling, B. A., \& Johnson, E. I. (2015). Conducting qualitative research on parental incarceration: Personal reflections on challenges and contributions. Qualitative Report, 20(10), 1550-1567.

Glatz, T., \& Buchanan, C. M. (2015). Change and predictors of change in parental self-efficacy from early to middle adolescence. Developmental Psychology, 51(10), 13671379. https://doi.org/10.1037/dev0000035

Glaze, L. E., \& Maruschak, L. M. (2010). Parents in prison and their minor children. Issues and Lessons for Incarcerated and Released Parents, 101-135.

Kementerian Hukum dan Hak Asasi Manusia. (1995). Undang-Undang Republik Indonesia Nomor 12 Tahun 1995 Tentang Pemasyarakatan. 1-22.

Kjellstrand, J. M., \& Eddy, J. M. (2011). Parental Incarceration During Childhood, Family Context, and Youth Problem Behavior Across Adolescence. Journal of Offender Rehabilitation, 50(1), 18-36. https://doi.org/10.1080/10509674.2011.53672 0

Loper, A. B., \& Tuerk, E. H. (2011). Improving the Emotional Adjustment and Communication Patterns of Incarcerated Mothers: Effectiveness of a Prison Parenting Intervention. Journal of Child and Family Studies, 20(1), 89-101. https://doi.org/10.1007/s10826-010-9381-8

Magee, L. (2016). Parenting under stress:

Examining the protective role of parenting selfefficacy in a high-risk environment. ProQuest Dissertations and Theses, 96. https://login.ezproxy.javeriana.edu.co/login?qu rl=https $\% 3 A \% 2 F \% 2 F$ search.proquest.com $\% 2$ Fdocview\%2F1868416810\%3Faccountid\%3D 13250

Mustofa, M., West, B. S., Sri Supadmi, M., \& Sari, H. (2019). Challenges to mothering while incarcerated: preliminary study of two women's prisons in Java, Indonesia. International Journal of Prisoner Health, 15(1), 37-45. https://doi.org/10.1108//JPH-06-2017-
0031

Rana, S. A., Akhtar, S., \& Tahir, M. A. (2013). Parenting Styles and Social Anxiety among Pakistani Adolescents. Journal of New Horizons, 7(2), 21-34.

Sistem Data Base Pemasyarakatan. (2017). Data Terakhir Jumlah Penghuni Perkanwil. http://smslap.ditjenpas.go.id/public/grl/current/ monthly

Stewart-Brown, S. (2008). Improving parenting: the why and the how. Archives of Disease in Childhood, 93(2), 102 LP - 104. https://doi.org/10.1136/adc.2006.113522

The Sentencing Project. (2018). Incarcerated Women and Girls. The Sentencing Project, 15. http://www.sentencingproject.org/wpcontent/uploads/2016/02/IncarceratedWomen-and-Girls-1980-2016.pdf

Valdez, R. S., McGuire, K. M., \& Rivera, A. J. (2017). Qualitative ergonomics/human factors research in health care: Current state and future directions. Applied Ergonomics, 62, 4371.

https://doi.org/10.1016/j.apergo.2017.01.016

Walmsley, R. (2017). World female imprisonment list: Fourth edition, women and girls in penal institutions, including pre-trial detainees/remand prisoners. World Prison Brief, 1-13. http://www.prisonstudies.org/news/worldfemale-imprisonment-list-fourth-edition Wildeman, C., \& Turney, K. (2014). Positive, Negative, or Null? The Effects of Maternal Incarceration on Children's Behavioral Problems. Ciencia e Saude Coletiva. https://doi.org/https://doi.org/10.1007/s13524014-0291-z

World Prison Brief. (2016). Female prison population: trend. https://www.prisonstudies.org/country/indonesi a

Yunardhani, R. (2013). EFEKTIFITAS LEMBAGA PEMASYARAKATAN DI INDONESIA. Jurnal Sosiologi, 15(18), 143-149. 